Фармацевтична технологія, біофармація, гомеопатія

Pharmaceutical technology, biopharmacy, homeopathy

Рекомендована д. фрармац. наук, профр. Д. І. Дмитрієвським

УДК 615.453.6.013

DOI 10.11603/2312-0967.2017.3.8113

\title{
ОСНОВНІ ПІДХОДИ ДО ФОРМУЛЯЦІЇ ПАРЕНТЕРАЛЬНОЇ СУСПЕНЗІЇ НА ОСНОВІ СУБСТАНЦІї ГІДРОКОРТИЗОНУ АЦЕТАТ У КОМБІНАЦІї ІЗ МІСЦЕВИМ АНЕСТЕТИКОМ ЛІДОКАЇНУ ГІДРОХЛОРИДОМ
}

\author{
(C). I. Качапут, С. М. Гуреєва \\ Центральна лабораторія фрармацевтичної розробки \\ ПАТ «Фармак», Київ \\ o.kachaput@farmak.ua
}

\begin{abstract}
Мета роботи. Науково обґрунтувати вибір оптимальних кількостей допоміжних речовин в рамках фрормуляції парентеральної суспензії на основі субстанції гідрокортизону ацетат у комбінації із місцевим анестетиком лідокаїну гідрохлоридом, враховуючи вимоги настанови ICH Q8 «Фармацевтична розробка».

Матеріали і методи. При дослідженні були застосовані підходи, описані в настанові ICH Q8 «Фармацевтична розробка», та використані наступні аналітичні методи: високоефрективна рідинна хроматограсрія (ДФУ 2.2.29), потенціометричне титрування (ДФУ 2.2.20), лазерна дифракція (ДФУ 2.9.31), потенціометричне визначення рН (ДФУ 2.2.3), в'язкість (ДФУ 2.2.8), мікробіологічні випробування (ДФУ 2.6.1, 2.6.14).

Результати й обговорення. В рамках проведених досліджень згідно з настановою ICH Q8 «Фармацевтична розробка» було розроблено цільовий профріль якості парентеральної суспензії «Гідрокортизону ацетат + лідокаїну гідрохлорид» та проведено оцінку із визначення критичних показників якості. Всі ідентифріковані ризики фрормуляції було обґрунтовано і ті з них, що мали «середній» та «високий» рівень згідно з оцінкою, шляхом варіабельності змінних при експериментальних дослідженнях були знижені до рівня «низький».

Продемонстровано підхід до вибору концентрацій компонентів бусрерної системи та експериментально підтверджено оптимальність меж рН суспензії на рівні діапазону 5,0 - 7,0 для забезпечення стабільності готової лікарської форми.

Після проведення всього спектра досліджень було проведено переоцінку ризиків, що підтвердила зниження встановлених вище ризиків до прийнятних шляхом повної відповідності за основними показниками якості готової лікарської форми.

Висновки. На основі проведених досліджень науково обґрунтовано вибір оптимальних кількостей допоміжних речовин у рамках фрормуляції парентеральної суспензії на основі субстанції гідрокортизону ацетат у комбінації із місцевим анестетиком лідокаїну гідрохлоридом, враховуючи вимоги настанови ICH Q8 «Фармацевтична розробка».
\end{abstract}

Ключові слова: парентеральна суспензія; гідрокортизону ацетат; лідокаїну гідрохлорид; допоміжні речовини; формуляція; цільовий профріль якості продукту; критичні показники якості; ICH Q8.

Вступ. Відповідно до Державної фрармакопеї України (ДФУ) лікарські засоби для парентерального застосування - стерильні лікарські засоби, призначені для введення шляхом ін'єкцій або імплантацій в організм людини або тварини. Для виготовлення лікарських засобів для парентерального застосування використовують допоміжні речовини, наприклад, такі, що забезпечують ізотонічність лікарського засобу відносно крові, регулюють рН, покращують розчинність діючих речовин, запобігають їх розкладанню, забезпечують відповідні антимікробні властивості лікарських засобів. Ці речовини не мають негативно впливати на основну терапевтичну дію лікарського засобу або у використовуваних концентраціях не мають чинити токсичну дію або надмірне місцеве подразнення [1].
Суспензійна ін'єкційна фрорма лікарського засобу дає змогу вирішити ряд задач. Перевагами таких лікарських фрорм $є$ можливість пролонгування терапевтичного есректу, підвищення біодоступності малорозчинних субстанцій діючих речовин та одночасне використання несумісних активних фрармацевтичних інгредієнтів [2].

Лікарські препарати у формі суспензій для ін'єкцій в основному містять наступні групи допоміжних речовин: сурфактанти (забезпечення змочування гідрофробних сполук та стабілізація суспензій), компоненти бусрерної системи (регуляція рН середовища), антимікробні консерванти (забезпечення захисту від мікробного забруднення), антиоксиданти (забезпечення захисту від оксидативної деградації), суспендуючі агенти (стабілізація суспензій) та інші [3].

ISSN 2312-0967. Фармацевтичний часопис. 2017. № 3 
При виборі допоміжних речовин для майбутнього готового лікарського препарату, звичайно, також необхідно враховувати вимоги та підходи, що описані в настановах провідних регуляторних агенцій світу (європейська, американська, японська). Але варто зазначити, що в основі цих настанов лежать вимоги та рекомендації Міжнародної конореренції із гармонізації технічних вимог до реєстрації лікарських препаратів для людини (ICH) [4].

Мета роботи - науково обґрунтувати вибір оптимальних кількостей допоміжних речовин в рамках формуляції парентеральної суспензії на основі субстанції гідрокортизону ацетат у комбінації із місцевим анестетиком лідокаїну гідрохлоридом, враховуючи вимоги настанови ICH Q8 «Фармацевтична розробка» [5].

Методи дослідження. При дослідженні були застосовані підходи, описані в настанові ICH Q8 «Фармацевтична розробка» [5]. Напрацьовані лабораторні серії лікарського препарату були проаналізовані із
Фармацевтична технологія, біофармація, гомеопатія Pharmaceutical technology, biopharmacy, homeopathy

використанням валідованих аналітичних методик. При дослідженнях були використані наступні аналітичні методи: високоефективна рідинна хроматографрія (ДФУ 2.2.29), потенціометричне титрування (ДФУ 2.2.20), лазерна дифрракція (ДФУ 2.9.31), потенціометричне визначення рН (ДФУ 2.2.3), в'язкість (ДФУ 2.2.8), мікробіологічні випробування (ДФУ 2.6.1, 2.6.14).

Результати й обговорення. Відповідно до рекомендацій настанови ICH Q8 фармацевтична розробка готового лікарського препарату розпочинається із створення цільового просрілю якості продукту (ЦПЯП) та оцінки критичних показників якості (КПЯ) майбутнього лікарського препарату. Цільовий профріль якості парентеральної суспензії «Гідрокортизону ацетат + лідокаїну гідрохлорид» наведено в таблиці 1.

У таблиці 2 наведено характеристики якості лікарського препарату та вказано на те, які показники були класифріковані як критичні показники якості лікарського препарату в рамках фрормуляції.

Таблиця 1. Цільовий профріль якості продукту для суспензії «Гідрокортизону ацетат + лідокаїну гідрохлорид»

\begin{tabular}{|c|c|c|}
\hline Елемент ЦПЯП & Ціль & Обґрунтування \\
\hline Лікарська фрорма & Суспензія для ін'єкцій & $\begin{array}{l}\text { Відповідно до бажаного } \\
\text { терапевтичного ефректу } \\
\text { лікарського препарату }\end{array}$ \\
\hline Шлях введення & Парентеральний & $\begin{array}{l}\text { Відповідно до бажаного } \\
\text { терапевтичного ефекту } \\
\text { препарату }\end{array}$ \\
\hline Доза & $\begin{array}{l}\text { Гідрокортизону ацетат: } 25 \text { мг/мл } \\
\text { Лідокаїну гідрохлорид: } 5 \text { мг/мл }\end{array}$ & $\begin{array}{l}\text { Відповідно до бажаного } \\
\text { терапевтичного ефекту } \\
\text { препарату }\end{array}$ \\
\hline Стабільність & $\begin{array}{l}\text { Термін придатності не менше } 2 \text { років при } \\
\text { температурі не вище } 30^{\circ} \mathrm{C}\end{array}$ & $\begin{array}{l}\text { Відповідно до очікування для } \\
\text { дистрибуції }\end{array}$ \\
\hline \multirow{11}{*}{$\begin{array}{l}\text { Показники якості } \\
\text { лікарського препарату } \\
\text { (основні) }\end{array}$} & Опис & \multirow{11}{*}{$\begin{array}{l}\text { Вимоги Європейської та США } \\
\text { фрармакопей, а також інших } \\
\text { стандартів якості }\end{array}$} \\
\hline & Кількісне визначення & \\
\hline & Супровідні домішки & \\
\hline & $\mathrm{pH}$ & \\
\hline & Розмір часток & \\
\hline & Ресуспендованість & \\
\hline & Стійкість до осідання & \\
\hline & В'язкість & \\
\hline & Об'єм, що витягається & \\
\hline & Стерильність & \\
\hline & Бактеріальні ендотоксини & \\
\hline Система упаковки & $\begin{array}{l}\text { Придатна система упаковки для забезпечення } \\
\text { цільового строку зберігання та забезпечення } \\
\text { стабільності суспензії під час транспортування }\end{array}$ & $\begin{array}{l}\text { Вимоги до отримання } \\
\text { необхідної дози та стабільності } \\
\text { суспензії }\end{array}$ \\
\hline Застосування & $\begin{array}{l}\text { Попередні дані: разова доза } 5 \text { - } 50 \text { мг } \\
\text { гідрокортизону ацетату. Не більше 3-х ін'єкцій } \\
\text { в різні суглоби на добу. Повторне введення } \\
\text { препарату через } 3 \text { тижні. }\end{array}$ & $\begin{array}{l}\text { Відповідно до бажаного } \\
\text { терапевтичного ефекту } \\
\text { препарату }\end{array}$ \\
\hline $\begin{array}{l}\text { Альтернативний метод } \\
\text { застосування }\end{array}$ & Попередні дані: відсутній & Не передбачено \\
\hline
\end{tabular}

ISSN 2312-0967. Pharmaceutical review. 2017. № 3 
Фармацевтична технологія, біофармація, гомеопатія Pharmaceutical technology, biopharmacy, homeopathy

Таблиця 2. Цільовий профріль якості продукту для суспензії «Гідрокортизону ацетат + лідокаїну гідрохлорид» (опис критичності показників якості для формуляції)

\begin{tabular}{|c|c|c|c|}
\hline $\begin{array}{c}\text { Показники якості } \\
\text { лікарського препарату }\end{array}$ & Ціль & КПЯ & Обґрунтування \\
\hline Опис & $\begin{array}{l}\text { Біла або майже біла, легко } \\
\text { струшувана суспензія із } \\
\text { характерним запахом }\end{array}$ & $\mathrm{Hi}$ & $\begin{array}{l}\text { Колір непрямо впливає на безпечність та } \\
\text { еорективність. Тому показник оцінено як } \\
\text { не критичний в рамках фрормуляції. Ціль } \\
\text { встановлює прийнятність для пацієнта }\end{array}$ \\
\hline Кількісне визначення & $\begin{array}{l} \pm 5 \% \text { від номінального } \\
\text { значення }\end{array}$ & Так & $\begin{array}{l}\text { Варіабельність кількісного вмісту впливає на } \\
\text { безпеку та ефективність для пацієнта. Тому } \\
\text { даний показник визначений як критичний }\end{array}$ \\
\hline Супровідні домішки & $\begin{array}{l}\text { Нормування згідно } 3 \\
\text { вимогами настанови ICH } \\
\text { Q3B }\end{array}$ & Так & $\begin{array}{l}\text { Межа продуктів розкладання діючих речовин } \\
\text { має вирішальне значення для безпеки } \\
\text { лікарського препарату. Нормування продуктів } \\
\text { деградації відповідає настанові ICH Q3B }\end{array}$ \\
\hline $\mathrm{pH}$ & $5.0-7.0$ & Так & $\begin{array}{l}\text { При встановленні оптимального значення } \\
\text { рН готового продукту забезпечується } \\
\text { максимальна стійкість лікарського засобу } \\
\text { протягом життєвого циклу препарату }\end{array}$ \\
\hline Розмір часток & $\begin{array}{l}100 \text { \% часток мають бути } \\
\text { меншими } 30 \text { мкм }\end{array}$ & Так & $\begin{array}{l}\text { Розподіл часток за розміром впливає на } \\
\text { пролонгованість терапевтичного ефекту. Тому } \\
\text { даний показник визначений як критичний }\end{array}$ \\
\hline Ресуспендованість & $\begin{array}{l}\text { Після інтенсивного } \\
\text { струшування протягом } \\
1-2 \text { хв препарат повинен } \\
\text { утворювати гомогенну } \\
\text { суспензію, вільну від } \\
\text { коагульованих часток }\end{array}$ & Так & $\begin{array}{l}\text { Ресуспендованість впливає на зручність } \\
\text { застосування препарату та однорідність } \\
\text { розподілення діючої речовини в препараті. } \\
\text { Даний показник визначено як критичний }\end{array}$ \\
\hline Стійкість до осідання & Не менше 5 хв & Так & $\begin{array}{l}\text { Даний показник впливає на зручність } \\
\text { застосування препарату та однорідність } \\
\text { розподілення діючої речовини в препараті }\end{array}$ \\
\hline В'язкість & $2-10 \mathrm{~m} \mathrm{a}^{*} \mathrm{c}$ & Так & $\begin{array}{l}\text { Даний показник прямо впливає на стабільність } \\
\text { суспензії та інші показники якості, тому був } \\
\text { визначений як критичний }\end{array}$ \\
\hline Об'єм, що витягається & Не менше 2 мл & $\mathrm{Hi}$ & $\begin{array}{l}\text { Має бути достатнім для гарантованого } \\
\text { добування номінальної дози. Ця ціль не } \\
\text { впливає на безпеку або ефективність для } \\
\text { пацієнта та не залежить від фрормуляції } \\
\text { препарату. Тому показник оцінено як не } \\
\text { критичний в рамках формуляції }\end{array}$ \\
\hline Стерильність & $\begin{array}{l}\text { Препарат повинен бути } \\
\text { стерильним }\end{array}$ & Так & $\begin{array}{l}\text { Даний показник напряму впливає на безпеку } \\
\text { пацієнта }\end{array}$ \\
\hline $\begin{array}{l}\text { Бактеріальні } \\
\text { ендотоксини }\end{array}$ & Не більше 35 МО/мл & Так & $\begin{array}{l}\text { Високі значення бактеріальних ендотоксинів } \\
\text { будуть впливати на безпеку пацієнта }\end{array}$ \\
\hline
\end{tabular}

Під час формуляції парентеральної суспензії було проведено первинну оцінку ризиків показників якості субстанції діючої речовини та варіабельність формуляції.

Дана оцінка ризиків включала в себе попередні знання і досвід з формулюваннями подібних лікарських фрорм і інформацію про лікарську речовину гідрокортизону ацетат. Оскільки кінцевий виробничий процес не був створений на момент оцінки ризику, тому зміни, які можуть бути пом'якшені шляхом коригування процесу виробництва, були оцінені як більш низький ризик. Ці фрактори були отримані в ході роз- робки технологічного процесу. У процесі оцінки ризику кількісні фрактори були внесені в таблицю та поділені на три категорії: високий, середній та низький.

Оцінку ризиків показників якості діючої речовини гідрокортизону ацетат наведено в таблиці 3.

На наступному етапі досліджень проводилася оцінка ризиків варіабельності фрормуляції. Для цього вибрані для досліджень допоміжні речовини було оцінено за їх впливом на КПЯ розроблюваної суспензії (табл. 4).

Всі ідентисріковані ризики фрормуляції було обґрунтовано і ті з них, що мали рівень «середній» та «висо-

ISSN 2312-0967. Фармацевтичний часопис. 2017. № 3 
Фармацевтична технологія, біофармація, гомеопатія Pharmaceutical technology, biopharmacy, homeopathy

Таблиця 3. Первинна оцінка ризиків показників якості діючої речовини гідрокортизону ацетат

\begin{tabular}{|c|c|}
\hline КПя лікарського засобу & $\begin{array}{c}\text { Лікарська речовина } \\
\text { (гідрокортизону ацетат) }\end{array}$ \\
\hline Кількісне визначення & Низький \\
\hline Супровідні домішки & Середній \\
\hline $\mathrm{pH}$ & Низький \\
\hline Розмір часток & Високий \\
\hline Ресуспендованість & Низький \\
\hline Стійкість до осідання & Низький \\
\hline В'язкість & Низький \\
\hline Стерильність & Низький \\
\hline Бактеріальні ендотоксини & Середній \\
\hline
\end{tabular}

кий», шляхом варіабельності змінних були знижені до рівня «низький». Для цього було напрацьовано ряд лабораторних серій з метою детального дослідження кожного із вибраних допоміжних речовин для оцінки їх впливу на критичні показники якості готової лікарської форми згідно з оцінкою наведеною в таблиці 4.

Наприклад, при оцінці ризиків було встановлено, що на значення та стабільність показника $\mathrm{pH}$ будуть суттєво впливати тільки компоненти буфрерної системи (натрію гідрофоссрат додекагідрат та натрію дигідросроссрат дигідрат), тому в рамках експериментальних робіт було встановлено точні концентрації даних компонентів, враховуючи значення цільових меж показника $\mathrm{pH}$ згідно з даними в таблиці 2. Результати даних експериментальних робіт наведено в таблиці 5.
Як видно із даних таблиці 5, враховуючи бажані цільові межі значень рН препарату, оптимальним співвідношенням двох компонентів бусерної системи $€$ співвідношення лабораторної серії 3.

Додатково 3 метою підтвердження вибраних цільових меж $\mathrm{pH}$ були проведені дослідження модельних розчинів розроблюваної суспензії з більш широкими значеннями рН, ніж цільові межі 5,0 - 7,0.

Більш високі та низькі значення рН було досягнуто за рахунок додавання 1 М розчину натрію гідроксиду чи 1 М розчину кислоти хлористоводневої. Отримані модельні розчини мали значення рН в діапазоні від 3,0 до 9,0. Залежність основних показників якості суспензії для ін'єкцій «Гідрокортизону ацетат + Лідокаїну гідрохлорид» від початкових значень $\mathrm{pH}$ розчину протягом досліджуваного терміну зберігання за

Таблиця 4. Первинна оцінка ризиків варіабельності фрормуляції парентеральної суспензії «Гідрокортизону ацетат + лідокаїну гідрохлорид»

\begin{tabular}{|c|c|c|c|c|c|c|c|c|}
\hline \multirow[b]{2}{*}{$\begin{array}{c}\text { КПя } \\
\text { лікарського } \\
\text { засобу }\end{array}$} & \multicolumn{8}{|c|}{ Допоміжні речовини } \\
\hline & $\begin{array}{c}\text { Метилпара- } \\
\text { гідрокси- } \\
\text { бензоат }\end{array}$ & $\begin{array}{c}\text { Пропілпара- } \\
\text { гідрокси- } \\
\text { бензоат }\end{array}$ & $\begin{array}{l}\text { Натрію } \\
\text { хлорид }\end{array}$ & $\begin{array}{c}\text { Натрію } \\
\text { гідро- } \\
\text { фоссорат } \\
\text { додека- } \\
\text { гідрат }\end{array}$ & $\begin{array}{l}\text { Натрію } \\
\text { дигідро- } \\
\text { фоссфат } \\
\text { дигідрат }\end{array}$ & $\begin{array}{l}\text { Повідон } \\
\text { К-17 }\end{array}$ & $\begin{array}{c}\text { Полісорбат } \\
80\end{array}$ & $\begin{array}{l}\text { Диметил- } \\
\text { ацетамід }\end{array}$ \\
\hline $\begin{array}{c}\text { Кількісне } \\
\text { визначення }\end{array}$ & Низький & Низький & Низький & Низький & Низький & Низький & Низький & Низький \\
\hline $\begin{array}{c}\text { Супровідні } \\
\text { домішки }\end{array}$ & Низький & Низький & Низький & Низький & Низький & Низький & Низький & Низький \\
\hline $\mathrm{pH}$ & Низький & Низький & Низький & Високий & Високий & Низький & Низький & Низький \\
\hline $\begin{array}{l}\text { Розмір } \\
\text { часток }\end{array}$ & Низький & Низький & Низький & Низький & Низький & Низький & Низький & Низький \\
\hline $\begin{array}{l}\text { Ресуспен- } \\
\text { дованість }\end{array}$ & Низький & Низький & Середній & Низький & Низький & Середній & Середній & Високий \\
\hline $\begin{array}{c}\text { Стійкість до } \\
\text { осідання }\end{array}$ & Низький & Низький & Середній & Низький & Низький & Високий & Середній & Середній \\
\hline В'язкість & Низький & Низький & Низький & Низький & Низький & Високий & Низький & Низький \\
\hline $\begin{array}{l}\text { Стериль- } \\
\text { ність }\end{array}$ & Середній & Середній & Низький & Низький & Низький & Низький & Низький & Низький \\
\hline $\begin{array}{l}\text { Бактеріальні } \\
\text { ендотоксини }\end{array}$ & Низький & Низький & Низький & Низький & Низький & Низький & Низький & Низький \\
\hline
\end{tabular}

ISSN 2312-0967. Pharmaceutical review. 2017. № 3 
Фармацевтична технологія, біофармація, гомеопатія Pharmaceutical technology, biopharmacy, homeopathy

Таблиця 5. Встановлення кількості компонентів буферної системи суспензії

\begin{tabular}{|c|c|c|c|c|}
\hline \multirow{2}{*}{$\begin{array}{l}\text { Компоненти бусрерної } \\
\text { системи/рН суспензії }\end{array}$} & \multicolumn{4}{|c|}{ Номер лабораторної серії } \\
\hline & 1 & 2 & 3 & 4 \\
\hline $\begin{array}{l}\text { Натрію гідрофосфрат } \\
\text { додекагідрат }\end{array}$ & 0,5 мг/мл & 1,0 мг/мл & 6,0 мг/мл & 15,0 мг/мл \\
\hline $\begin{array}{l}\text { Натрію дигідрофроссрат } \\
\text { дигідрат }\end{array}$ & 5,0 мг/мл & 7,5 мг/мл & 10,0 мг/мл & 10,0 мг/мл \\
\hline $\begin{array}{l}\text { Значення рН суспензії } \\
\text { (враховуючи наявність } \\
\text { інших компонентів } \\
\text { препарату) }\end{array}$ & 5,09 & 5,27 & 6,08 & 6,91 \\
\hline
\end{tabular}

стресових температурних умов (6 місяців, $\left.60^{\circ} \mathrm{C}\right)$ наведено в таблиці 6.

Отримані результати досліджень вказують на ріст ідентифрікованих та неідентифрікованих домішок гідрокортизону ацетату за більш кислих та більш лужних значень $\mathrm{pH}$ порівняно із вибраними межами $\mathrm{pH}$ $(5,0-7,0)$. Разом із ростом домішок спостерігається логічне падіння кількісного вмісту гідрокортизону ацетату та лідокаїну гідрохлориду (падіння кількісного вмісту гідрокортизону ацетату є більш вираженим). За більш нейтральних значень рН досліджуваної суспензії протягом досліджуваного періоду не було виявлено значного росту домішок та падіння кількісного вмісту діючих речовин готової лікарської фрорми.
Таким чином, отримані результати досліджень підтвердили оптимальність меж рН суспензії на рівні діапазону 5,0 - 7,0 для забезпечення стабільності готової лікарської фрорми в часі та дозволили обрати оптимальні концентрації компонентів буферної системи.

Після проведення всього спектра експериментальних робіт з метою зниження ризиків формуляції відповідно до первинної оцінки (табл. 4) згідно з рекомендаціями настанови ICH Q8 «Фармацевтична розробка» було проведено переоцінку ризиків, що підтвердила зниження встановлених вище ризиків до прийнятних шляхом повної відповідності за основними показниками якості готової лікарської фрорми (табл. 7).

Таблиця 6. Залежність основних показників якості досліджуваної суспензії від рН середовища

\begin{tabular}{|c|c|c|c|c|c|c|c|}
\hline \multirow{2}{*}{\multicolumn{2}{|c|}{ рH середовища }} & \multirow{2}{*}{\multicolumn{2}{|c|}{$\begin{array}{c}\text { Кількісний вміст } \\
\text { гідрокортизону ацетату / } \\
\text { лідокаїну гідрохлориду, } \\
\text { мг/мл }\end{array}$}} & \multicolumn{4}{|c|}{ Супровідні домішки гідрокортизону ацетату } \\
\hline & & & & \multicolumn{2}{|c|}{$\begin{array}{c}\text { будь-яка ідентифрікована } \\
\text { домішка, \% }\end{array}$} & \multicolumn{2}{|c|}{$\begin{array}{c}\text { будь- яка } \\
\text { неідентифрікована } \\
\text { домішка, \% }\end{array}$} \\
\hline вихідне & $\begin{array}{c}\text { кінцеве } \\
(6 \text { міс. } \\
60^{\circ} \mathrm{C} \text { ) }\end{array}$ & вихідне & $\begin{array}{l}\text { кінцеве } \\
(6 \text { міс. } \\
\left.60^{\circ} \mathrm{C}\right)\end{array}$ & вихідне & $\begin{array}{l}\text { кінцеве } \\
(6 \text { міс. } \\
\left.60^{\circ} \mathrm{C}\right)\end{array}$ & вихідне & $\begin{array}{c}\text { кінцеве } \\
(6 \text { міс. } \\
60^{\circ} \mathrm{C} \text { ) }\end{array}$ \\
\hline 3,03 & 3,12 & $25,12 / 5,03$ & $24,11 / 4,92$ & $\begin{array}{l}0,21 \\
0,12 \\
\end{array}$ & $\begin{array}{l}2,17 \\
0,86 \\
\end{array}$ & 0,07 & 0,43 \\
\hline 5,12 & 5,14 & $25,09 / 5,01$ & $25,22 / 5,09$ & $\begin{array}{l}0,21 \\
0,12\end{array}$ & $\begin{array}{l}0,54 \\
0,32\end{array}$ & 0,08 & 0,20 \\
\hline 6,07 & 6,05 & $25,11 / 4,99$ & $25,08 / 5,03$ & $\begin{array}{l}0,21 \\
0,12\end{array}$ & $\begin{array}{l}0,41 \\
0,27\end{array}$ & 0,07 & 0,15 \\
\hline 7,92 & 8,08 & $25,12 / 5,04$ & $24,77 / 4,87$ & $\begin{array}{l}0,21 \\
0,12\end{array}$ & $\begin{array}{l}0,75 \\
0,34\end{array}$ & 0,07 & 0,16 \\
\hline 9,04 & 8,91 & $25,01 / 5,08$ & $23,72 / 4,71$ & $\begin{array}{l}0,21 \\
0,12\end{array}$ & $\begin{array}{l}2,45 \\
0,84\end{array}$ & 0,07 & $\begin{array}{l}0,54 \\
0,18\end{array}$ \\
\hline
\end{tabular}

Таблиця 7. Вплив результатів фрормуляції парентеральної суспензії «Гідрокортизону ацетат + лідокаїну гідрохлорид» на первинну оцінку ризиків

\begin{tabular}{|c|c|c|c|c|c|c|c|c|}
\hline \multirow{2}{*}{$\begin{array}{c}\text { Критичні } \\
\text { показники } \\
\text { якості }\end{array}$} & $\begin{array}{c}\text { Метилпара- } \\
\text { гідрокси- } \\
\text { бензоат }\end{array}$ & $\begin{array}{c}\text { Пропілпара- } \\
\text { гідрокси- } \\
\text { бензоат }\end{array}$ & $\begin{array}{c}\text { Натрію } \\
\text { хлорид }\end{array}$ & $\begin{array}{c}\text { Натрію } \\
\text { гідрососорат } \\
\text { додекагідрат }\end{array}$ & $\begin{array}{c}\text { Натрію } \\
\text { дигідро- } \\
\text { досрат } \\
\text { дигідрат }\end{array}$ & $\begin{array}{c}\text { Повідон } \\
\text { К-17 }\end{array}$ & $\begin{array}{c}\text { Полісорбат } \\
80\end{array}$ & $\begin{array}{c}\text { Диметил- } \\
\text { ацетамід }\end{array}$ \\
\hline 1 & 2 & 3 & 4 & 5 & 6 & 7 & 8 & 9 \\
\hline $\begin{array}{c}\text { Кількісне } \\
\text { визначення }\end{array}$ & Низький & Низький & Низький & Низький & Низький & Низький & Низький & Низький \\
\hline
\end{tabular}

ISSN 2312-0967. Фармацевтичний часопис. 2017. № 3 
Фармацевтична технологія, біофармація, гомеопатія Pharmaceutical technology, biopharmacy, homeopathy

Продовження табл. 7

\begin{tabular}{|c|c|c|c|c|c|c|c|c|}
\hline 1 & 2 & 3 & 4 & 5 & 6 & 7 & 8 & 9 \\
\hline $\begin{array}{c}\text { Супровідні } \\
\text { домішки }\end{array}$ & Низький & Низький & Низький & Низький & Низький & Низький & Низький & Низький \\
\hline рН & Низький & Низький & Низький & Низький & Низький & Низький & Низький & Низький \\
\hline $\begin{array}{c}\text { Розмір } \\
\text { часток }\end{array}$ & Низький & Низький & Низький & Низький & Низький & Низький & Низький & Низький \\
\hline $\begin{array}{c}\text { Ресуспен- } \\
\text { дованість }\end{array}$ & Низький & Низький & Низький & Низький & Низький & Низький & Низький & Низький \\
\hline $\begin{array}{c}\text { Стійкість до } \\
\text { осідання }\end{array}$ & Низький & Низький & Низький & Низький & Низький & Низький & Низький & Низький \\
\hline \begin{tabular}{c} 
В'язкість \\
\hline $\begin{array}{c}\text { Стериль- } \\
\text { ність }\end{array}$
\end{tabular} Низький & Низький & Низький & Низький & Низький & Низький & Низький & Низький \\
\hline $\begin{array}{c}\text { Бактеріальні } \\
\text { ендотоксини }\end{array}$ & Низький & Низький & Низький & Низький & Низький & Низький & Низький & Низький \\
\hline
\end{tabular}

Висновки. На основі проведених досліджень було науково обґрунтовано вибір оптимальних кількостей допоміжних речовин в рамках фрормуляції парентеральної суспензії на основі субстанції гідрокортизону ацетат у комбінації із місцевим анестетиком лідокаїну гідрохлоридом, враховуючи вимоги настанови ICH Q8 «Фармацевтична розробка». Проведені експери- ментальні роботи дозволили мінімізувати ризики по впливу допоміжних речовин на критичні показники якості готової лікарської форми та забезпечили високий відсоток впевненості у стабільності фрармацевтичної композиції для відповідності якості парентеральної суспензії розробленому цільовому профрілю якості препарату.

\section{ОСНОВНЫЕ ПОДХОДЫ К ФОРМУЛЯЦИИ ПАРЕНТЕРАЛЬНОЙ СУСПЕНЗИИ НА ОСНОВЕ СУБСТАНЦИИ ГИДРОКОРТИЗОНА АЦЕТАТ В КОМБИНАЦИИ С МЕСТНЫМ АНЕСТЕТИКОМ ЛИДОКАИНА ГИДРОХЛОРИДОМ}

\section{А. И. Качапут, С. Н. Гуреева}

Центральная лаборатория фрармацевтической разработки

ПАО «Фармак», Киев

o.kachaput@farmak.ua

Цель работы. Научно обосновать выбор оптимальных количеств вспомогательных веществ в рамках формуляции парентеральной суспензии на основе субстанции гидрокортизона ацетат в комбинации с местным анестетиком лидокаина гидрохлоридом, учитывая требования руководства ICH Q8 «Фармацевтическая разработка».

Материалы и методы. При исследовании были применены подходы, описанные в руководстве ICH Q8 «Фармацевтическая разработка» и использованы следующие аналитические методы: высокоэффективная жидкостная хроматограсрия (ГФУ 2.2.29), потенциометрическое титрование (ГФУ 2.2.20), лазерная дифрракция (ГФУ 2.9.31), потенциометрическое определение рН (ГФУ 2.2.3), вязкость (ГФУ 2.2.8), микробиологические испытания (ГФУ 2.6.1, 2.6.14).

Результаты и обсуждение. В рамках проведенных исследований согласно руководства ICH Q8 «Фармацевтическая разработка» был разработан целевой просиль качества парентеральной суспензии «Гидрокортизона ацетат + лидокаина гидрохлорид» и проведена оценка по определению критических показателей качества. Все идентифицированные риски формуляции было обосновано и те из них, которые имели «средний» и «высокий» уровень согласно оценке путем вариабельности переменных при экспериментальных исследованиях были снижены до уровня «низкий».

Продемонстрировано подход к выбору концентраций компонентов буфрерной системы и экспериментально подтверждено оптимальность пределов рН суспензии на уровне диапазона 5,0 - 7,0 для обеспечения стабильности готовой лекарственной формы.

После проведения всего спектра исследований было проведено переоценку рисков, которая подтвердила снижение установленных выше рисков до приемлемых путем полного соответствия по основным показателям качества готовой лекарственной формы.

ISSN 2312-0967. Pharmaceutical review. 2017. № 3 
Фармацевтична технологія, біофармація, гомеопатія

Pharmaceutical technology, biopharmacy, homeopathy

Выводы. На основе проведенных исследований научно обоснован выбор оптимальных количеств вспомогательных веществ в рамках формуляции парентеральной суспензии на основе субстанции гидрокортизона ацетат в комбинации с местным анестетиком лидокаина гидрохлоридом, учитывая требования руководства ICH Q8 «Фармацевтическая разработка».

Ключевые слова: парентеральная суспензия; гидрокортизона ацетат; лидокаина гидрохлорид; вспомогательные вещества; формуляция; целевой просиль качества продукта; критические показатели качества; ICH Q8.

\title{
THE MAIN APPROACHES TO FORMULATION OF PARENTERAL SUSPENSION BASED ON HYDROCORTISONE ACETATE DRUG SUBSTANCE IN COMBINATION WITH LOCAL ANESTHETICS OF LIDOCAINE HYDROCHLORIDE
}

\section{O. I. Kachaput, S. M. Gureyeva}

\author{
Central Laboratory of Pharmaceutical Development \\ Farmak JSC, Kyiv \\ o.kachaput@farmak.ua
}

The aim of the work. Scientifically justifying the optimal amounts choice of excipients in the formulation of the parenteral suspension based on hydrocortisone acetate drug substance in combination with local anesthetic of lidocaine hydrochloride, taking into account the requirements of $\mathrm{ICH}$ Q8 «Pharmaceutical development» guideline.

Materials and Methods. The approaches described in the ICH Q8 «Pharmaceutical development» were used and the following analytical methods were used: high performance liquid chromatography (SPU 2.2.29), potentiometric titration (SPU 2.2.20), laser diffraction (SPU 2.9.31), potentiometric determination of pH (SPU 2.2.3), viscosity (SPU 2.2.8), microbiological tests (SPU 2.6.1, 2.6.14).

Results and Discussion. The quality target product profile of the parenteral suspension «Hydrocortisone acetate + lidocaine hydrochloride» was developed and an assessment was made for the determination of critical quality attributes within conducted researches according to ICH Q8 «Pharmaceutical development» guideline. All identified formulation risks were justified, and those that had a «medium» and «high» levels according to the assessment, by ways of the variability of variables in the experimental studies was reduced to «low» level.

The approach to choosing of the concentrations of buffer system components have been demonstrated and the experimentally confirmed the optimality range of the $\mathrm{pH}$ values of suspension at the range of $5.0-7.0$ for the stability of the finished dosage form.

After conducting the entire spectrum of research, a reassessment of risks was carried out, which confirmed the reduction of the above risks to acceptable by ways of full compliance with the main quality attributes of the finished dosage form.

Conclusions. Based on conducted research, the choice of optimal amounts of excipients within the formulation of parenteral suspension based on hydrocortisone acetate drug substance in combination with local anesthetic of lidocaine hydrochloride, taking into account the requirements of ICH Q8 «Pharmaceutical development» guideline, was scientifically justified.

Key words: parenteral suspension; hydrocortisone acetate; lidocaine hydrochloride; excipients; formulation; quality target product profile; critical quality attributes; ICH Q8.

\section{Список літератури}

1. Державна Фармакопея України / Державне підприємство «Український науковий фрармакопейний центр якості лікарських засобів». - 2-е вид. - Харків Державне підприємство «Український науковий фрармакопейний центр якості лікарських засобів», 2015. - T. 1. - C. $1090-1093$.

2. Kulshreshtha Alok K. Pharmaceutical suspensions From Formulation Development to Manufacturing / K. Kulshreshtha Alok, N. Onkar Singh, G. Wall - London: Michael Springer New York Dordrecht Heidelberg, 2010. $327 \mathrm{p}$.

3. Качапут О. І. Дослідження асортименту допоміжних речовин, які використовують у лікарських препаратах у формі суспензій для ін'єкцій, зареєстрованих на ринку України / О. І. Качапут, С. М. Гуреєва // Фармацевтичний часопис. - 2015. - № 2 (34). - С. 36 - 39.

4. Міжнародна конференція по гармонізації технічних вимог до реєстрації лікарських препаратів для людини. [Електронний ресурc]. http://www.ich.org/home.html 5. Настанова Міжнародної конференції із гармонізації технічних вимог до реєстрації лікарських препаратів для людини ICH Q8. [Електронний ресурс]. http://www.ich. org/products/guidelines/quality/article/quality-guidelines. html

ISSN 2312-0967. Фармацевтичний часопис. 2017. № 3 
Фармацевтична технологія, біофармація, гомеопатія Pharmaceutical technology, biopharmacy, homeopathy

\section{References}

1. Ukrainian Scientific Pharmacopoeial Center for Quality of Medicines. State Pharmacopoeia of Ukraine. [Державна Фармакопея України]. 2nd ed. Vol. 1. Kharkiv: Ukrainian Scientific Pharmacopoeial Center for Quality of Medicines; 2015, 1090-3. Ukrainian.

2. Kulshreshtha Alok K, Singh Onkar N, Wall G Michael, editors. Pharmaceutical suspensions From formulation development to manufacturing. London: Michael Springer New York Dordrecht Heidelberg; 2010.

3. Kachaput OI, Hureieva SM. [The research of excipient's assortment used in finished drug products in suspensions forms for injection, which are registered in Ukraine]. Farmatsevt chasop. 2015;2: 36-9. Ukrainian.

4. International Conference on Harmonization of Technical Requirements for Registration of Pharmaceuticals for Human Use. - Available from: http://www.ich.org/home.html. 5. International Conference on Harmonization of Technical Requirements for Registration of Pharmaceuticals for Human Use ICH Q8. - Available from: http://www.ich.org/products/guidelines/quality/article/quality-guidelines.html

Отримано 19.07.2017 